\title{
Analisis Strategi Pemasaran Produk Kerupuk Rumput Laut Pada Pusat Pelatihan Mandiri Kelautan dan Perikanan (P2MKP) Kota Balikpapan Kalimantan Timur
}

\author{
Suwardi Gunawan $^{* 1}$, Willy Tambunan ${ }^{2}$, Ahmad Subarkah ${ }^{3}$ \\ ${ }^{1,2}$ Program Studi Teknik Industri, Fakultas Teknik, Universitas Mulawarman \\ E-mail: gunawansuwardi@gmail.com
}

\begin{abstract}
ABSTRAK
Pusat Pelatihan Mandiri Kelautan dan Perikanan (P2MKP) merupakan bidang usaha budidaya dan pengolahan rumput laut yang berlokasi di Jalan Mulawarman Gang Anyer RT 13 No.44 Kelurahan Manggar, Kecamatan Balikpapan, Kota Balikpapan. Penjualan yang dilakukan tidak memiliki strategi khusus dalam pemasarannya, hanya sebatas memenuhi permintaan yang ada. Formulasi strategi dimulai dengan tahap pengumpulan input dasar perumusan strategi yaitu identifikasi dan analisis faktor-faktor lingkungan internal dan eksternal perusahaan. Tahap selanjutnya yaitu pencocokan dan memadukan faktor internal maupun eksternal. Hasil dari matriks IFE dan EFE dimasukkan ke dalam matriks IE untuk mengetahui posisi perusahaan. Setelah diketahui posisi perusahaan dalam matriks IE dilakukan analisis SWOT untuk merumuskan alternatif strategi. Selanjutnya diambil keputusan yang akan menjadi prioritas dengan menggunakan metode AHP sebagai rekomendasi strategi perusahaan. Sehingga didapatkan strategi utama yakni: (1) Menjalin hubungan dengan pemerintah untuk melakukan perizinan produk, (2) Menciptakan pengembangan produk dengan menggunakan teknologi dan melakukan koordinasi dengan pihak terkait untuk melakukan perizinan BPOM RI dan label halal, (3) Menjalin hubungan kerjasama dan dukungan pemerintah dalam memperluas daerah pemasaran, (4) Meningkatkan volume produksi atau persediaan dengan penggunaan teknologi, (5) Efisiensi biaya produksi dengan mempertahankan harga produk, strategi keenam adalah membangun kemitraan untuk meningkatkan kualitas produk sehingga tercipta costumer value.
\end{abstract}

Kata kunci : P2MKP, Rumput Laut, Kerupuk Rumput laut, SWOT

\begin{abstract}
Pusat Pelatihan Mandiri Kelautan dan Perikanan (P2MKP) is a seaweed cultivation business field that located in Jalan Mulawarman Gang Anyer RT.13 No. 44 Manggar, Balikpapan City, East Kalimantan. The selling method they applied has no specific strategy in marketing, the selling method they applied only provide current needs of customers.Strategy formulation starts with the input stage to formulating the strategy; identify and analyze the factors of internal and external company's environment. The next stage is the matching stage to result a proper strategy alternative with combining the internal and external factors. The result of IFE and EFE matrix included into IE matrix to detect company location. After the location of company was detected in the IE matrix, then SWOT analysis was required to formulate strategy alternative. The last stage, decision stage, it decides which one will be the priority with using Analysis Hierarchy Process as recommended strategy for the company. It results strategy is;(1) Maintain a relationship with the government to get patent product license, (2) To create an innovation of products with using technology and occur coordination with related instances to get BPOM RI and halal certification, (3) To maintain a cooperation to get government support in widening the marketing area, (4) Increasing production or stocks volume with using technology, (5) To reach the efficient production cost with maintaining the same product price, and the sixth strategy is build the partnerships to increasing the quality of product so the customer value is achieved.
\end{abstract}

Keywords : P2MKP, Seaweed, seaweed crackers, SWOT

\section{PENDAHULUAN}

Analisis Strategi Pemasaran Produk Kerupuk Rumput Laut Pada Pusat Pelatihan Mandiri Kelautan dan Perikanan (P2MKP) Kota Balikpapan Kalimantan Timur / Suwardi Gunawan, Willy Tambunan, Ahmad Subarkah

Peer reviewed under responsibili of Universitas Muhammadiyah Sidoarjo. (C) 2019 Universitas Muhammadiyah Sidoarjo. All Right reserved. This is an open access article under the CC BY licence (http://creativecommons.org/licences/by/4.0/) 
Negara Indonesia merupakan negara kepulauan dengan berbagai macam keanekaragam hasil laut, salah satunya adalah rumput laut. Tumbuhan yang hidup di laut ini merupakan salah satu jenis komoditas unggulan yang memiliki nilai ekonomi pasar yang kompetitif baik di pasar dalam negeri maupun ekspor. Berbagai jenis rumput laut Indonesia tersebut, terdapat beberapa jenis bernilai ekonomis dan telah diperdagangkan, baik untuk konsumsi domestik maupun ekspor. Rumput laut ini sudah diolah menjadi berbagai macam olahan. Saat ini salah satu olahan rumput laut yang telah dikenal masyarakat adalah kerupuk rumput laut.

Manajemen pemasaran adalah salah satu kegiatan pokok yang dilakukan oleh perusahaan untuk mempertahankan kelangsungan perusahaannya, berkembang, dan mendapatkan laba. Proses pemasaran itu dimulai jauh sebelum barang-barang diproduksi, dan tidak berakhir dengan penjualan.

Pengambilan keputusan tidak jarang ditemukan banyak faktor yang menjadi pertimbangan, sehingga menyulitkan untuk mengambil suatu keputusan yang terbaik. Pengambilan keputusan yang banyak melibatkan faktor, maka perlu digunakan suatu metode tertentu.salah satu metode pengambilan keputusan adalah metode Analytic Hierarchy Process atau sering disebut AHP

Salah satu usaha budidaya dan pengolahan rumput laut adalah Pusat Pelatihan Mandiri Kelautan dan Perikanan (P2MKP) yang berlokasi di Jalan Mulawarman Gang Anyer RT 13 No. 44 Kelurahan Manggar, Kecamatan Balikpapan, Kota Balikpapan-Kaltim. Awal berdirinya P2MKP hanya sekedar Kelompok Tani Sumber Laut Berjaya yang dikelola oleh Bapak Yakub dan telah banyak mendapatkan prestasi diantaranya adalah sebagai penggerak budidaya rumput laut di daerah Balikpapan.

Saat ini banyak usaha dan perusaahan yang menyadari akan pentingnya pengelolaan manajemen pemasaran yang baik untuk menghadapi tantangan dari luar. Begitu pula dengan pusat pelatihan mandiri kelautan dan perikanan yang menyadari hal ini sehingga dibutuhkan suatu rumusan alternatif strategi yang diperlukan agar pusat pelatihan mandiri kelautan dan perikanan dapat memperkuat posisi usaha dan produk dalam menghadapai persaingan usaha. Strategi yang dijalankan saat ini oleh pusat pelatihan mandiri kelautan dan perikanan kurang optimal pelaksanaan dan pencapainnya. Dengan permintaan produk semakin meningkat khususnya untuk produk kerupuk sehingga mendorong peneliti untuk melakukan perumusan strategi pemasaran yang nantinya akan diajukan sebagai usulan perbaikan untuk tempat penelitian khususnya dalam pemasaran produk kerupuk rumput laut.

Pemasaran adalah analisis, perencanaan, implementasi dan pengendalian dari program - program yang dirancang untuk menciptakan, membangun dan memelihara pertukaran yang menguntungkan dengan pembeli sasaran untuk mencapai tujuan perusahaan[1]. Sedangkan Manajemen adalah proses perencanaan (Planning), pengorganisasian (Organizing), pergerakan (Actuating) dan pengawasan (Controling)[2].

Faktor internal merupakan gambaran kondisi suatu perusahaan yaitu faktor kekuatan dan kelemahan[3]. Perusahaan menghindari ancaman yang berasal dari faktor eksternal melalui kekuatan yang dimilikinya dari faktor internal. Sedangkan kelemahannya dari faktor internal dapat diminimalkan dengan melihat peluang dan faktor eksternalnya. Segmentasi, target dan posisi pasar serta bauran pemasaran akan dibahas adalah sebagai berikut:

1. Segmentation, Targeting, Positioning

Segmentasi pasar adalah kegiatan membagi-bagi pasar yang bersifat heterogen dari suatu produk ke dalam satuan-satuan pasar atau segmen pasar yang bersifat homogen. Targeting merupakan sebuah sasaran, siapa yang dituju. Dalam menentukan targeting maka dilakukan beberapa survey untuk dapat mengetahui keadaan pasar nantinya. Posisioning adalah persepsi atau tanggapan konsumen mengenai posisi yang dipegang oleh setiap produk di pasar [3].

2. Bauran Pemasaran

Bauran pemasaran adalah seperangkat alat pemasaran yang digunakan perusahaan untuk mencapai tujuan pemasarannya dalam pasar sasaran[3]. Salah satu strategi pemasaran yang dapat dilakukan perusahaan adalah melalui bauran pemasaran (marketing mix) yang terdiri dari empat unsur yang dikenal sebagai 4P, yaitu Product (produk), Price (Harga), Place (Tempat), dan Promotion (Promosi).

Perumusan ini diharapkan untuk mempertahankan kelangsungan usaha untuk memasarkan produk ditengah persaingan usaha yang begitu tinggi.

\section{METODE}

Analisis Strategi Pemasaran Produk Kerupuk Rumput Laut Pada Pusat Pelatihan Mandiri Kelautan dan Perikanan (P2MKP) Kota Balikpapan Kalimantan Timur / Suwardi Gunawan, Willy Tambunan, Ahmad Subarkah

Peer reviewed under responsibili of Universitas Muhammadiyah Sidoarjo. (C) 2019 Universitas Muhammadiyah Sidoarjo. All Right reserved. This is an open access article under the CC BY licence (http://creativecommons.org/licences/by/4.0/) 
Data-data yang diperlukan dalam melakukan penelitian ini meliputi dua jenis data yaitu data primer dan data sekunder. Data primer merupakan data yang diambil langsung dari sumbernya. Dalam penelitian ini meliputi wawancara langsung dengan pihak terkait melaui kusioner untuk kemudian dapat dijadikan data primer. Jenis data yang kedua yang digunakan adalah data sekunder yang mana data ini adalah data yang telah tersedia yang dimiliki oleh tempat penelitian. selanjutnya adalah melakukan pengolahan data. Dalam proses pengolahn data, data yang diperoleh kemudian di analisa dengan beberapa langkah analisa, antara lain: (1) Mengidentifikasi lingkungan internal (kekuatan dan kelemahan) perusahaan melalui aspek STP dan marketing mix, (2) Menganalisis aspek pada lingkungan internal perusahaan dan merumuskanya ke dalam matriks IFE serta menganalisis aspek pada lingkungan eksternal perusahaan dan merumuskanya ke dalam matriks EFE, Matriks IE merupakan gabungan dari matriks IFE dan EFE [4]. (3) Dengan acuan matriks IFE dan EFE, strategi diformulasikan dengan matriks SWOT, Matriks SWOT adalah alat yang dipakai untuk menyususn faktor-faktor strategi perusahaan [4]. (4) Menentukan prioritas strategi pada masing-masing elemen yang dapat diterapkan oleh perusahaan dengan menggunakan Metode AHP. (5) Pengolahan pengujian AHP.

\section{HASIL DAN PEMBAHASAN}

Analisis lingkungan internal diarahkan pada aspek-aspek tertentu, yakni pada aspek STP dan bauran pemasaran. Berdasarkan hasil pengamatan dan wawancara langsung maka dapat diuraikan untuk masing-masing segmentasi, target dan posisi pasar sebagai berikut:

1. Segmentasi (Segmentation)

Segmentasi yang dilakukan adalah segmentasi geografis dimana Pusat Pelatihan Mandiri Kelautan dan Perikanan Kota Balikpapan berada pada kawasan pantai yang padat penduduk. Lokasi penetapan Pusat Pelatihan Mandiri Kelautan dan Perikanan ini berdekatan dengan jalan poros utama Kota Balikpapan dan keramaian seperti pasar dan pemukiman masyarakat.

2. Target (Targeting)

Target pasar berasal dari pasar bawaan, masyarakat sekitar tempat usaha, ataupun orang-orang yang berada disekeliling konsumen atau orang terdekat dengan konsumen tetap yang telah pernah membeli produk ini.

3. Posisi Pasar (Positioning)

Pusat Pelatihan Mandiri Kelautan dan Perikanan memposisikan diri untuk selalu memberikan olahan rumput laut yang digemari oleh seluruh masyarakat yang kaya akan kandungan gizi.

\section{Bauran Pemasaran}

Berdasarkan hasil pengamatan dan wawancara langsung maka dapat diuraikan untuk masing-masing bauran pemasaran pada Pusat Pelatihan Mandiri Kelautan dan Perikanan Kota Balikpapan adalah sebagai berikut:

1. Produk (Product)

Salah satu produk yang di buat oleh Pusat Pelatihan Mandiri Kelautan dan Perikanan yaitu produk kerupuk rumput laut yang memiliki kualitas baik, dengan nilai gizi yang tinggi, memiliki rasa yang enak yang sekaligus dapat menyehatkan dan berkhasiat. Sebagai makanan vegetarian, Produk kerupuk rumput laut ini memiliki banyak manfaat untuk kesehatan, karena mengandung air $(27,8 \%)$, protein $(5,4 \%)$, karbohidrat $(33,3 \%)$, lemak $(8,6 \%)$ serat kasar $(3 \%)$ dan abu $(22,25 \%)$.

2. Harga (Price)

Harga yang di tawarkan untuk satu bungkus produk yang mentah adalah sebesar Rp. 75.000,00/Kg dan untuk produk yang telah matang (telah digoreng) sebesarRp 5.000,00/Bungkus.

3. Tempat (Place)

Pusat Pelatihan Mandiri Kelautan dan Perikanan didirikan di Jalan Mulawarman Gang Anyer RT.13 No. 44 Kelurahan Manggar, Kecamatan Balikpapan. Tempat pendirian ini terletak sekitar $1 \mathrm{~km}$ tidak jauh dari jalan poros utama Kota Balikpapan.

4. Promosi (Promotion)

Promosi yang telah dilakukan untuk mempromosikan produk kerupuk rumput laut ini belum maksimal dimana promosi yang dilakukan hanya sekedar promosi dari konsumen satu ke konsumen lain.

Analisis Strategi Pemasaran Produk Kerupuk Rumput Laut Pada Pusat Pelatihan Mandiri Kelautan dan Perikanan (P2MKP) Kota Balikpapan Kalimantan Timur / Suwardi Gunawan, Willy Tambunan, Ahmad Subarkah

Peer reviewed under responsibili of Universitas Muhammadiyah Sidoarjo. (C) 2019 Universitas Muhammadiyah Sidoarjo. All Right reserved. This is an open access article under the CC BY licence (http://creativecommons.org/licences/by/4.0/) 
Prozima, Vol 3, No.1, Juni 2019, 33-42

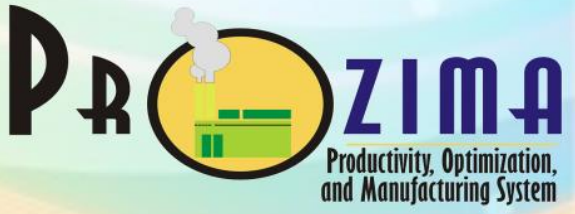

E. ISSN. 2541-5115

Journal Homepage: http://ojs.umsida.ac.id/index.php/prozima

DOI Link: http://doi.org/10.21070/prozima.v3i1.1266

Article DOI: http://doi.org/10.21070/prozima.v3i1.1266

\section{Analisis Lingkungan Eksternal}

Analsisi lingkungan ekternal yang dilakukan meliputi analisis lingkungan eksternal yang dibedakan menjadi lingkungan mikro dan lingkungan makro.

\section{Analisis Lingkungan Mikro}

Lingkungan mikro perusahaan terdiri dari para pelaku dalam lingkungan yang langsung berkaitan dengan perusahaan yang mempengaruhi kemampuannya untuk melayani pasar.

1. Pemasok

Rumput laut ini di dapatkan langsung dari hasil budidaya produk ini sendiri dan dari hasil budidaya petani rumput laut di sekitar tempat usaha.

2. Perantara

Produk kerupuk rumut laut langsung di pasarakan kepada konsumen atau kepada agen penjualan.

3. Pelanggan

memiliki beberapa pelanggan tetap yang biasa membeli produk kerupuk rumput laut, diantara pelanggannya seperti masyarakat sekitar, agen-agen, dan lembaga yang memiliki hubungan kemitraan dengan usaha.

4. Pesaing

Pusat Pelatihan Mandiri Kelautan dan Perikanan belum memiliki pesaing yang pasti dikarenakan Pusat Pelatihan Mandiri Kelautan dan Perikanan ini merupakan satu-satunya usaha pengolahan kerupuk rumput laut.

\section{Analisis Lingkungan Makro}

Analisis lingkungan makro terdiri dari faktor-faktor yang ada dari luar perusahaan.

1. Faktor Ekonomi

Jika kondisi ekonomi suatu negara baik maka maka akan meningkatkan daya beli masyarakat dinegara tersebut yang akhirnya akan mempengaruhi kondisi makro ekonomi negara tersebut.

2. Faktor Sosial Budaya

Sistem sosial dalam kegiatan budidaya rumput laut masih memiliki ikatan yang sangat kuat. Secara umum kebiasaan bergotong royong dalam melakukan suatu pekerjaan masih terpelihara dengan baik.

3. Faktor Teknologi

Faktor teknologi yang berkembang pesat telah merubah pada seluruh aspek kehidupan manusia. Di abad 21 ini telah banyak ditemukan peralatan baru yang semakin mempermudah pekerjaan manusia.

\section{Identifikasi Kekuatan, Kelemahan, Peluang, dan Ancaman}

Perumusan strategi pemasaran dimulai dari tahap analisis faktor internal dan eksternal perusahaan yang dirumuskan menjadi kekuatan, kelemahan, peluang dan ancaman.

\section{Identifikasi Kekuatan, Kelemahan}

Kekuatan dan kelemahan yang dimiliki oleh Pusat Pelatihan Mandiri Kelautan dan Perikanan adalah sebagai berikut:

1. Kekuatan
a. Bahan baku mudah didapat
b. Kandungan gizi yang baik
c. Rumput laut tidak tergantung Musim
d. Harga jual relatif stabil
e. Kerupuk tahan lama

Analisis Strategi Pemasaran Produk Kerupuk Rumput Laut Pada Pusat Pelatihan Mandiri Kelautan dan Perikanan (P2MKP) Kota Balikpapan Kalimantan Timur / Suwardi Gunawan, Willy Tambunan, Ahmad Subarkah

Peer reviewed under responsibili of Universitas Muhammadiyah Sidoarjo. 
2. Kelemahan
a. Tidak ada manejemen terpadu
b. Peralatan manual dan tradisional
c. Kurangnya promosi produk
d. Belum adanya perizinan produk
e. Kemasan kurang menarik
f. Proses penjemuran menggunakan sinar matahari

\section{Identifikasi Peluang, Ancaman}

Peluang dan ancaman yang dimiliki oleh Pusat Pelatihan Mandiri Kelautan dan Perikanan adalah sebagai berikut:

1. Peluang
a. Peluang besar untuk dikembangkan
b. Dukungan pemerintah terhadap usaha
c. Tersedia media promosi internet
d. Keuntungan yang cukup besar
e. Masyarakat menyukai produk kerupuk
f. Hanya sedikit olahan rumput laut

2. Ancaman
a. Produk mudah ditiru
b. Pesaing menawarkan harga lebih murah
c. Kenaikan harga bahan baku dan pelengkap
d. Pesaing dengan jumlah dan rasa yang beragam
e. Tuntutan izin BPOM dan label Halal
f. Cuaca kurang mendukung mengganggu proses penjemuran rumput laut

\section{Perumusan Strategi Pemasaran}

Perumusan strategi pemasaran dilakukan dengan dua tahapan yaitu tahapan input dan tahapan pencocokan.

\section{Tahap Input}

Tahap input terdapat 2 matriks yang digunakan yaitu matriks EFE dan IFE.

1. Analisis Matriks Internal Factor Evaluation (IFE)

Tabel 1. Matriks IFE

\begin{tabular}{|c|c|c|c|}
\hline KEKUATAN & $\begin{array}{l}\text { Bobot } \\
\text { (a) }\end{array}$ & $\begin{array}{l}\text { Rating } \\
\text { (b) }\end{array}$ & $\begin{array}{l}\text { Skor } \\
\text { (axb) }\end{array}$ \\
\hline Bahan baku mudah didapat & 0,087 & 3,5 & $\mathbf{0 , 3 0 4}$ \\
\hline Memiliki kandungan gizi yang baik & 0,111 & 4 & 0,444 \\
\hline Rumput laut tidak tergantung Musim & 0,076 & 3,5 & 0,267 \\
\hline Harga jual relatif stabil & 0,075 & 3,5 & 0,261 \\
\hline Kerupuk lebih tahan lama & 0,097 & 3,5 & $\mathbf{0 , 3 4 0}$ \\
\hline Harga produk yang bersaing & 0,078 & 3,5 & $\mathbf{0 , 2 7 3}$ \\
\hline \multicolumn{4}{|l|}{ KELEMAHAN } \\
\hline Tidak ada manajemen terpadu & 0,071 & 1,5 & $\mathbf{0 , 1 0 7}$ \\
\hline Peralatan manual dan tradisional & 0,094 & 1,5 & $\mathbf{0 , 1 4 1}$ \\
\hline Kurangnya promosi produk & 0,075 & 1,5 & $\mathbf{0 , 1 1 2}$ \\
\hline Belum adanya perizinan produk & 0,118 & 1,5 & $\mathbf{0 , 1 7 7}$ \\
\hline Kemasan kurang menarik & 0,069 & 1,5 & $\mathbf{0 , 1 0 4}$ \\
\hline Penjemuran menggunakan sinar matahari & 0,049 & 1 & 0,049 \\
\hline
\end{tabular}

Analisis Strategi Pemasaran Produk Kerupuk Rumput Laut Pada Pusat Pelatihan Mandiri Kelautan dan Perikanan (P2MKP) Kota Balikpapan Kalimantan Timur / Suwardi Gunawan, Willy Tambunan, Ahmad Subarkah

Peer reviewed under responsibili of Universitas Muhammadiyah Sidoarjo. 
Pusat Pelatihan Mandiri Kelautan dan Perikanan memiliki kekuatan utama yaitu memiliki kandungan gizi yang baik dengan skor 0,444 dimana kekuatan ini yang nantinya akan terus dikembangkan dan dipertahankan.

\section{Analisis Matriks External Factor Evaluation (EFE)}

Tabel 2. Matriks EFE

\begin{tabular}{|c|c|c|c|}
\hline PELUANG & $\begin{array}{l}\text { Bobot } \\
\text { (a) }\end{array}$ & $\begin{array}{l}\text { Rating } \\
\text { (b) }\end{array}$ & $\begin{array}{l}\text { Skor } \\
\text { (axb) }\end{array}$ \\
\hline Peluang besar untuk dikembangkan & 0,083 & 3 & $\mathbf{0 , 2 5 0}$ \\
\hline Dukungan pemerintah terhadap usaha & 0,118 & 4 & $\mathbf{0 , 4 7 2}$ \\
\hline Tersedia media promosi internet & 0,097 & 4 & $\mathbf{0 , 3 8 9}$ \\
\hline Keuntungan yang cukup besar & 0,090 & 3,5 & $\mathbf{0 , 3 1 6}$ \\
\hline Masyarakat menyukai produk kerupuk & 0,092 & 3,5 & $\mathbf{0 , 3 2 2}$ \\
\hline Hanya sedikit olahan rumput laut & 0,106 & 4 & 0,424 \\
\hline \multicolumn{4}{|l|}{ ANCAMAN } \\
\hline Produk mudah ditiru & 0,064 & 1 & 0,064 \\
\hline Pesaing menawarkan harga lebih murah & 0,068 & 1 & $\mathbf{0 , 0 6 8}$ \\
\hline Kenaikan harga bahan baku dan bahan pelengkap & 0,069 & 2 & $\mathbf{0 , 1 3 9}$ \\
\hline $\begin{array}{l}\text { Berdirinya pesaing yang memproduksi dalam jumlah } \\
\text { dan rasa yang beragam }\end{array}$ & 0,073 & 2 & 0,146 \\
\hline Tuntutan izin BPOM dan label Halal & 0,090 & 2 & 0,181 \\
\hline Total & 1.00 & 31,000 & 2,770 \\
\hline
\end{tabular}

Pusat Pelatihan Mandiri Kelautan dan Perikanan memiliki peluang yang utama adalah dukungan pemerintah terhadap usaha dengan skor 0,472.

\section{Tahap Pencocokan}

Tahap pencocokan yang digunakan adalah matriks IE dan matriks SWOT.

1. Matriks IE

\begin{tabular}{|c|c|c|c|}
\hline 4 & $\begin{array}{c}\text { Tinggi } \\
3,00-3,99\end{array}$ & $\begin{array}{l}\text { Rata-Rata } \\
2,00-2,99 \\
\end{array}$ & $\begin{array}{c}\text { Lemah } \\
1,0-1,99\end{array}$ \\
\hline $\begin{array}{c}\text { Tinggi } \\
3,00-3,99\end{array}$ & $\begin{array}{c}1 \\
\text { Growth }\end{array}$ & $\stackrel{2}{\text { Growth }}$ & $\begin{array}{c}3 \\
\text { Retrenchment }\end{array}$ \\
\hline $\begin{array}{l}\text { Rata-Rata } \\
2,00-2,99\end{array}$ & $\stackrel{4}{\text { Stability }}$ & $\stackrel{5}{\text { Growth }}$ & $\begin{array}{c}6 \\
\text { Retrenchment }\end{array}$ \\
\hline $\begin{array}{c}\text { Lemah } \\
1, Q-1,99\end{array}$ & $\begin{array}{c}7 \\
\text { Growth }\end{array}$ & $\begin{array}{c}8 \\
\text { Growth }\end{array}$ & $\begin{array}{c}9 \\
\text { Retrenchment }\end{array}$ \\
\hline
\end{tabular}

Gambar 1. Matrik IE

Pusat Pelatihan Mandiri Kelautan dan Perikanan berada pada posisi sel 5. Hal ini menunjukkan bahwa strategi yang paling baik yang digunakana oleh Pusat Pelatihan Mandiri Kelautan dan Perikanan adalah strategi Grow and Build (Tumbuh dan Berkembang).

Analisis Strategi Pemasaran Produk Kerupuk Rumput Laut Pada Pusat Pelatihan Mandiri Kelautan dan Perikanan (P2MKP) Kota Balikpapan Kalimantan Timur / Suwardi Gunawan, Willy Tambunan, Ahmad Subarkah

Peer reviewed under responsibili of Universitas Muhammadiyah Sidoarjo. 
2. Matriks SWOT

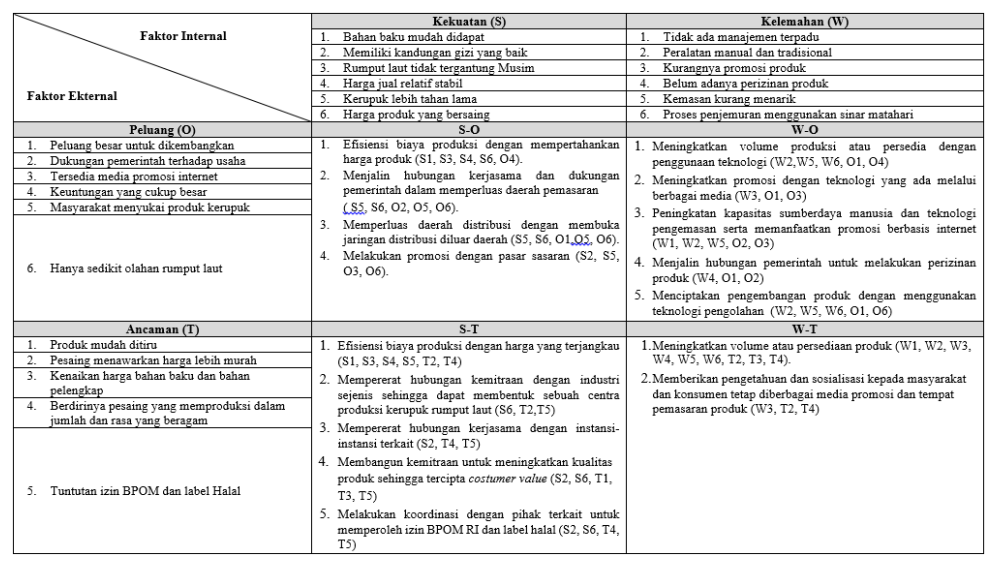

Gambar 2. Matriks SWOT

\section{Analysis Hierarchy Process}

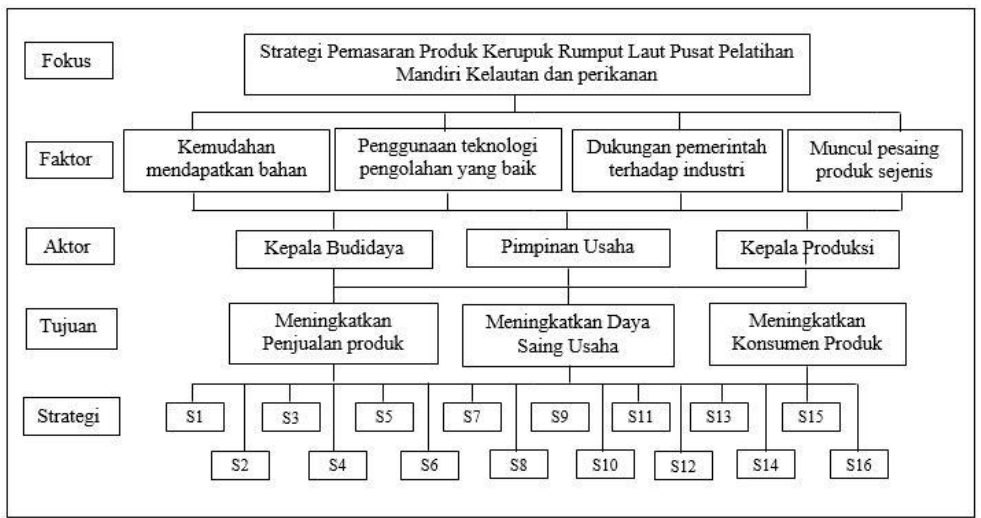

Gambar 3. Struktur hirarki

\section{Pengolahan Secara Horizontal}

Pengolahan horizontal digunakan untuk menyususn prioritas relatif setiap faktor yang berada satu tingkatan di atasnya.

1. Hasil Elemen Faktor terhadap Fokus

Tabel 3. Hasil Elemen Faktor Terhadap Fokus

\begin{tabular}{|l|c|c|}
\hline \multirow{2}{*}{ Elemen-Elemen Faktor } & \multicolumn{2}{c|}{ Fokus } \\
\cline { 2 - 3 } & Bobot & Prioritas \\
\hline Kemudahan mendapatkan bahan baku & 0,134 & $\mathbf{3}$ \\
\hline $\begin{array}{l}\text { Penggunaan teknologi pengolahan yang } \\
\text { baik }\end{array}$ & 0,518 & $\mathbf{1}$ \\
\hline Dukungan pemerintah terhadap industri & 0,285 & $\mathbf{2}$ \\
\hline Muncul pesaing produk sejenis & 0,063 & $\mathbf{4}$ \\
\hline \multicolumn{1}{|c|}{ Rasio Inkonsistensi (CR) } & \multicolumn{2}{|c|}{$\mathbf{1 3 0}$} \\
\hline
\end{tabular}

Analisis Strategi Pemasaran Produk Kerupuk Rumput Laut Pada Pusat Pelatihan Mandiri Kelautan dan Perikanan (P2MKP) Kota Balikpapan Kalimantan Timur / Suwardi Gunawan, Willy Tambunan, Ahmad Subarkah

Peer reviewed under responsibili of Universitas Muhammadiyah Sidoarjo. 
2. Hasil Elemen Aktor Terhadap Faktor

Tabel 4. Hasil Elemen Aktor Terhadap Faktor

\begin{tabular}{|l|c|c|c|c|}
\hline \multicolumn{1}{|c|}{ Elemen-elemen Aktor } & F1 & F2 & F3 & F4 \\
\hline Kepala Budidaya (A1) & 0,072 & 0,074 & 0,078 & 0,096 \\
\hline Pimpinan Usaha (A2) & 0,697 & 0,643 & 0,487 & 0,619 \\
\hline Kepala Produksi (A3) & 0,232 & 0,283 & 0,435 & 0,284 \\
\hline Rasio Inkonsistensi (CR) & $\mathbf{0 , 1 6 2}$ & $\mathbf{0 , 0 5 6}$ & $\mathbf{0 , 0 1 0}$ & $\mathbf{0 , 0 7 4}$ \\
\hline
\end{tabular}

3. Hasil Elemen Tujuan Terhadap Aktor

Tabel 5. Hasil Elemen Tujuan Terhadap Aktor

\begin{tabular}{|l|c|c|c|}
\hline \multicolumn{1}{|c|}{ Elemen-elemen Tujuan } & A1 & A2 & A3 \\
\hline Meningkatkan penjualan produk (T1) & 0,537 & 0,172 & 0,539 \\
\hline Meningkatkan Daya sainng Usaha (T2) & 0,195 & 0,350 & 0,164 \\
\hline Meningkatankan Konsumen (T3) & 0,268 & 0,478 & 0,297 \\
\hline Rasio Inkonsistensi (CR) & $\mathbf{0 , 1 1 8}$ & $\mathbf{0 , 1 1 8}$ & $\mathbf{0 , 0 0 8}$ \\
\hline
\end{tabular}

4. Hasil Elemen Strategi Terhadap Tujuan

Tabel 6. Hasil Elemen Terhadap Tujuan

\begin{tabular}{|c|c|c|c|}
\hline Elemen - elemen Alternatif & T1 & T2 & T3 \\
\hline S1 & 0,058 & 0,058 & 0,068 \\
\hline S2 & 0,070 & 0,076 & 0,089 \\
\hline S3 4 & 0,048 & 0,047 & 0,044 \\
\hline S5 & 0,108 & 0,101 & 0,132 \\
\hline S6 & 0,049 & 0,053 & 0,044 \\
\hline S7 & 0,074 & 0,073 & 0,068 \\
\hline S8 & 0,051 & 0,048 & 0,045 \\
\hline S9 10 & 0,050 & 0,052 & 0,045 \\
\hline S11 & 0,131 & 0,125 & 0,134 \\
\hline S12 & 0,047 & 0,046 & 0,042 \\
\hline S13 & 0,053 & 0,053 & 0,049 \\
\hline S14 & 0,041 & 0,041 & 0,038 \\
\hline S15 & 0,057 & 0,053 & 0,053 \\
\hline S16 & 0,113 & 0,121 & 0,107 \\
\hline Rasio Inkonsistensi (CR) & 0,027 & 0,028 & 0,024 \\
\hline & 0,024 & 0,024 & 0,021 \\
\hline & $\mathbf{0 , 0 9 6}$ & $\mathbf{0 , 1 0 4}$ & $\mathbf{0 , 1 0 2}$ \\
\hline
\end{tabular}

\section{Pengolahan Secara Vertikal}

Pengolahan vertikal di gunakan untuk menyusun dan melihat prioritas menyeluruh setiap elemen pada tingkat tertentu terhadap sasaran utama hirarki.

1. Fokus

Fokus pada hirarki ini adalah strategi pemasaran produk kerupuk rumput laut Pusat Pelatihan Mandiri Kelautan dan Perikanan

Analisis Strategi Pemasaran Produk Kerupuk Rumput Laut Pada Pusat Pelatihan Mandiri Kelautan dan Perikanan (P2MKP) Kota Balikpapan Kalimantan Timur / Suwardi Gunawan, Willy Tambunan, Ahmad Subarkah

Peer reviewed under responsibili of Universitas Muhammadiyah Sidoarjo. 
2. Faktor

Tabel 7. Hasil Pengolahan Vertikal Faktor

\begin{tabular}{|c|l|c|c|}
\hline \multicolumn{2}{|c|}{ Elemen-Elemen Faktor } & \multicolumn{2}{c|}{ Fokus } \\
\cline { 3 - 4 } & Bobot & Prioritas \\
\hline F1 & Kemudahan mendapatkan bahan baku & 0,134 & $\mathbf{3}$ \\
\hline F2 & Penggunaan teknologi pengolahan baik & 0,518 & $\mathbf{1}$ \\
\hline F3 & Dukungan pemerintah terhadap industri & 0,285 & $\mathbf{2}$ \\
\hline F4 & Muncul pesaing produk sejenis & 0,063 & $\mathbf{4}$ \\
\hline
\end{tabular}

\section{Aktor}

Tabel 8. Hasil Pengolahan Vertikal Aktor

\begin{tabular}{|l|c|c|}
\hline Elemen Aktor & Bobot & Prioritas \\
\hline Kepala budidaya (A1) & 0,080 & 3 \\
\hline Pimpinan Usaha (A2) & 0,612 & 1 \\
\hline Kepala Produksi (A3) & 0,309 & 2 \\
\hline
\end{tabular}

\section{Tujuan}

Tabel 9. Hasil Pengolahan Vertikal Tujuan

\begin{tabular}{|l|c|c|}
\hline \multicolumn{1}{|c|}{ Elemen Tujuan } & Bobot & Prioritas \\
\hline Meningkatkan penjualan produk (T1) & 0,416 & 1 \\
\hline Meningkatkan Daya saing Usaha (T2) & 0,236 & 3 \\
\hline Meningkatankan Konsumen (T3) & 0,348 & 2 \\
\hline
\end{tabular}

\section{Alternatif}

Tabel 10. Hasil pengolahan alternatif

\begin{tabular}{|c|c|c|}
\hline Elemen Strategi & Bobot & Prioritas \\
\hline Efisiensi biaya produksi dengan mempertahankan harga produk (S1) & 0,061 & 5 \\
\hline Menjalin hubungan kerjasama dan dukungan pemerintah (S2) & 0,078 & 3 \\
\hline Memperluas distribusi dengan membuka jaringan distribusi diluar daerah (S3) & 0,046 & 10 \\
\hline Melakukan promosi dan penetrasi pasar dengan pasar sasaran (S5) & 0,049 & 8 \\
\hline Meningkatkan volume produksi atau persedia dengan penggunaan teknologi (S6) & 0,072 & 4 \\
\hline Meningkatkan promosi dengan teknologi yang ada melalui berbagai media (S7) & 0,048 & 9 \\
\hline Menjalin hubungan pemerintah untuk melakukan perizinan produk (S9) & 0,130 & 1 \\
\hline Efisiensi biaya produksi harga yang terjangkau (S10) & 0,045 & 11 \\
\hline $\begin{array}{l}\text { Mempererat hubungan kemitraan dengan industri sejenis } \\
\text { dapat membentuk sebuah centra produksi kerupuk rumput laut (S11) }\end{array}$ & 0,052 & 7 \\
\hline Mempererat hubungan kerjasama dengan instansi-instansi terkait (S12) & 0,040 & 12 \\
\hline
\end{tabular}

Analisis Strategi Pemasaran Produk Kerupuk Rumput Laut Pada Pusat Pelatihan Mandiri Kelautan dan Perikanan (P2MKP) Kota Balikpapan Kalimantan Timur / Suwardi Gunawan, Willy Tambunan, Ahmad Subarkah

Peer reviewed under responsibili of Universitas Muhammadiyah Sidoarjo. (C) 2019 Universitas Muhammadiyah Sidoarjo. All Right reserved. This is an open access article under the CC BY licence (http://creativecommons.org/licences/by/4.0/ ) 


\section{SIMPULAN}

Berdasarkan penelitian yang di lakukan dapat disimpulkan bahwa strategi yang di rekomendasikan adalah menjalin hubungan dengan pemerintah untuk melakukan perizinan produk, strategi kedua adalah menciptakan pengembangan produk dengan menggunakan teknologi dan melakukan koordinasi dengan pihak terkait untuk melakukan perizinan BPOM RI dan label halal, strategi yang ketiga adalah menjalin hubungan kerjasama dan dukungan pemerintah dalam memperluas daerah pemasaran, strategi keempat adalah meningkatkan volume produksi atau persediaan dengan penggunaan teknologi, strategi kelima adalah efisiensi biaya produksi dengan mempertahankan harga produk, Strategi keenam adalah membangun kemitraan untuk meningkatkan kualitas produk sehingga tercipta costumer value.

\section{DAFTAR PUSTAKA}

[1] K. P. Keller KL, "Manajemen Pemasaran. In: Manajemen Pemasaran, Edisi 1.” Erlangga, Jakarta, pp. 1140, 2005.

[2] H. Umar, Strategic Managemen in Action. Jakarta: PT Gramedia Pustaka Utama, 2008.

[3] K. P. Gary A, Prinsip-Prinsip Pemasaran, Penerjemah : Maulana A, Hardani W. Jakarta: Prinsip-prinsip Pemasaran, 2009.

[4] F. Rangkuti, Analisis SWOT Teknik Membedah Kasus Bisnis. Jakarta: Gramedia Pustaka Utama, 2006.

Analisis Strategi Pemasaran Produk Kerupuk Rumput Laut Pada Pusat Pelatihan Mandiri Kelautan dan Perikanan (P2MKP) Kota Balikpapan Kalimantan Timur / Suwardi Gunawan, Willy Tambunan, Ahmad Subarkah

Peer reviewed under responsibili of Universitas Muhammadiyah Sidoarjo. 